\title{
Dietary and lifestyle factors contributing to insulin resistance
}

\author{
BY PATRICK M. BELL
}

Metabolic Unit, Royal Victoria Hospital, Belfast BT12 6BA

The present review focuses on some aspects of diet and exercise behaviour as they affect insulin sensitivity in both diabetic and healthy subjects. Insulin resistance, a less than normal biological effect for a given insulin concentration, is present in a number of common conditions including non-insulin-dependent diabetes mellitus (NIDDM), essential hypertension, hypertriacylglycerolaemia and obesity. Evidence that insulin resistance may be important in the pathogenesis of these conditions, and the fact that they are frequently present in the same patient, has led to speculation that insulin resistance is a common aetiological factor (Reaven, 1988). There is also both epidemiological and experimental support for the view that raised circulating insulin concentrations, a consequence of impaired insulin sensitivity, are a risk factor for vascular disease (Pyorala, 1979; Ducimetiere et al. 1980; Stout, 1992). The ability of pharmacological agents used in the treatment of both NIDDM and essential hypertension to alter insulin action is relevant to the choice of therapy in these diseases (Harper et al. 1996).

Against this background of the potential importance of insulin resistance both to causation and treatment of common conditions, which carry a significant morbidity and mortality, effects of changes in diet and exercise upon insulin sensitivity are of considerable interest. In the present review only studies in human subjects are considered and the emphasis is on work where effects of insulin on glucose metabolism have been measured directly, usually involving the euglycaemic hyperinsulinaemic clamp technique.

\section{EXERCISE AND INSULIN SENSITIVITY IN MAN}

Over 25 years ago Bjorntorp et al. (1970) demonstrated lower insulin concentrations in response to oral glucose in obese patients after a programme of exercise which improved physical fitness. The effects were independent of changes in body weight. Since blood glucose concentrations did not change, the lower circulating insulin concentrations were interpreted as indicating increased sensitivity to insulin. Bjorntorp et al. (1972) also showed in cross-sectional studies that fit subjects had lower insulin concentrations than less-fit individuals. Subsequent workers have measured whole-body insulin action directly using the euglycaemic hyperinsulinaemic clamp technique and confirmed that those exercising regularly are more insulin sensitive than sedentary subjects (Rosenthal et al. 1983).

Improved insulin sensitivity follows a single bout of exercise and this effect wears off after 2-5 d (Schneider et al. 1984; Mikines et al. 1988, 1989). It has been considered that acute effects probably account for most of the improvements in insulin sensitivity seen during physical training programmes. Thus, whilst training in association with weight loss improves insulin action (Bogardus et al. 1984), if weight is maintained by increased energy intake and the effect of the last bout of exercise is controlled, insulin sensitivity remains unaltered despite an improvement in cardio-respiratory fitness (Segal et al. 1991). More recent work examining a programme of one-legged exercise using the other non-exercised leg as a control has demonstrated a genuine training effect on glucose clearance which 
could not be elicited by acute exercise but which quickly diminished after detraining (Dela et al. 1992, 1995).

Acute-exercise effects can be demonstrated after relatively mild exercise. A similar increase in insulin sensitivity followed cycle ergometer exercise at $40 \%$ maximal $\mathrm{O}_{2}$ consumption compared with a higher-intensity exercise regimen (Young et al. 1989). It is also of interest that eccentric exercise (downhill running) resulting in muscle damage is followed by a period of insulin resistance compared with concentric exercise on a bicycle ergometer (Kirwan et al. 1992). Some caution is needed, therefore, in issuing rather nonspecific exercise prescriptions in the hope of reducing insulin resistance.

Under hyperinsulinaemic conditions prevailing in the euglycaemic clamp protocols used to assess insulin sensitivity in most of the studies mentioned previously, the majority of glucose disposal is in skeletal muscle (De Fronzo et al. 1981; Nuutila et al. 1994). A number of potential mechanisms exist by which the effect of insulin on the skeletal-muscle cell might be increased (Table 1). Reduced increases in insulin-mediated skeletal-muscle blood flow may contribute to insulin resistance in obesity, non-insulin- and insulindependent diabetes mellitus (Laakso et al. 1990; Baron et al. 1991a,b). Leg blood flow after insulin stimulation in athletes is $30 \%$ higher than that in sedentary controls (Hardin $e t$ al. 1995) and, in the same subjects, exercised legs have increased blood flow compared with non-exercised legs (Dela et al. 1992). Thus, exercise-induced changes in skeletalmuscle blood flow may be important determinants of improved insulin sensitivity.

Non-oxidative glucose disposal (largely storage as glycogen) is the major component of the increased insulin-mediated glucose disposal in response to exercise (Bogardus et al. 1984; Hardin et al. 1995) and in keeping with this exercise-induced increases in glycogen synthase (EC 2.4.1.21) activity have been demonstrated (Taylor et al. 1972; Mikines et al. 1988). It seems unlikely, however, that this is a major rate-limiting factor for insulin resistance, as free glucose does not accumulate in skeletal muscle even at high rates of glucose flux (Katz et al. 1988). Furthermore, a defect in insulin-mediated glucose uptake remains in NIDDM subjects despite normal activation of glycogen synthase (Devlin et al. 1987). It seems likely that glucose transport may be the more significant abnormality. In trained subjects compared with sedentary subjects, protein content of the predominant skeletal-muscle glucose transporter GLUT 4 is increased (Houmard et al. 1991; Hardin et al. 1995), although the effect may differ between muscle groups.

Finally, investigators have considered muscle fibre types based on observations that type I and IIa fibres exhibit increased insulin-mediated glucose uptake and GLUT 4 expression compared with type IIb fibres. A negative correlation between insulin sensitivity and type IIb fibre number has been demonstrated (Lillioja et al. 1987; Houmard et al. 1991), but other workers have found no relationship (Andersen et al. 1993; Hardin et al. 1995). Muscle capillary density is similar in trained athletes when compared with controls (Ebeling et al. 1993).

Table 1. Potential mechanisms for altered insulin sensitivity in skeletal muscle 


\section{EXERCISE AND NON-INSULIN-DEPENDENT DIABETES MELLITUS}

The primacy of insulin resistance in the aetiology of NIDDM remains controversial. Genetic factors as well as abnormalities of both insulin secretion and insulin resistance probably all contribute. Several lines of evidence favour a central role for insulin resistance. First, insulin resistance has an inherited component, at least in some populations (Bogardus et al. 1989; Groop et al. 1993). Second, abnormalities of insulin resistance can be identified in non-diabetic subjects at high risk of developing NIDDM (Leslie et al. 1986; Eriksson et al. 1989). Third, a progression from normal glucose tolerance to NIDDM has been traced in the more-insulin-resistant members of two populations (Saad et al. 1989; Martin et al. 1992).

Evidence is accumulating that regular physical exercise may prevent subsequent diabetes. Some inactive urban communities have higher rates of NIDDM than comparable rural communities (Zimmet et al. 1981). Cross-sectional studies indicate a higher prevalence of NIDDM in less-active than more-active subjects (Dowse et al. 1991). Prospective data are also available from two large studies. Helmrich et al. (1991) used questionnaire responses from 14 years previously to assess exercise behaviour in male college alumni. There was a clear increase in the incidence of NIDDM as estimated energy expenditure on leisure time physical activity declined from 14.6 to $2.1 \mathrm{MJ} /$ week. The association persisted when data were adjusted for age, obesity, hypertension and a parental history of diabetes. The protective effect appeared strongest for those at highest risk of NIDDM. Manson et al. (1991) carried out an 8-year follow-up of female nurses. Those engaging in vigorous exercise at least once weekly had a reduced risk of diabetes, which persisted after adjustment for body weight, family history of diabetes and age. The nature of the relationship between exercise and diabetes incidence in these studies is not clear, but could be caused by a direct effect of exercise on insulin sensitivity or an indirect effect through weight reduction or prevention of weight gain (Blair et al. 1985). Support for the protective effect of exercise also comes from a recent report from the Malmo study of risk factor intervention. In a prospective follow-up of non-diabetic middle-aged men in whom physical fitness was objectively documented there was a much-reduced progression to frank diabetes in those who were fitter at entry to the study (Eriksson \& Lindgarde, 1996).

The insulin resistance of NIDDM is characterized both by hepatic glucose overproduction and reduced skeletal-muscle glucose uptake. Reduced insulin-mediated glucose uptake in muscle and associated reduced oxidation and storage of glucose are partly compensated by glucose mass action because of prevailing hyperglycaemia. It is not possible to identify a single abnormality which explains skeletal-muscle insulin resistance. Reduced insulin-mediated skeletal-muscle blood-flow responses (Baron et al. 1991a), alteration in insulin receptor and second-messenger activity, as well as reduced glucose transport and activity of key enzymes such as glycogen synthase may all be important (De Fronzo et al. 1992).

Exercise-mediated improvements in insulin action and consequent lowering of prevailing blood glucose concentrations are an attractive option in managing NIDDM. Improved insulin-mediated skeletal-muscle glucose uptake is largely by non-oxidative pathways (Bogardus et al. 1984; Devlin et al. 1987), and a relationship with the acute effects of the last exercise bout have been described (Schneider et al. 1984; Segal et al. 1991). Recently Dela et al. (1995) described clear improvements in insulin action in the exercised leg of diabetic patients compared with the non-exercised leg. Although shortlived, the effect could not be mimicked by acute exercise and suggested a genuine training effect. These changes were associated with increased blood flow and glucose extraction in response to insulin and also increases in glycogen synthase mRNA and GLUT 4 protein 
mRNA (Dela et al. 1994). As in non-diabetic subjects, relatively-low-intensity exercise can be effective in NIDDM patients (Braun et al. 1995). It should be remembered that any treatment intervention resulting in improved glycaemic control is likely to be accompanied by reduced insulin resistance (Firth et al. 1986).

At least within the discipline of a clinical trial, exercise programmes do improve glycaemic control (Bogardus et al. 1984; Yamanouchi et al. 1995). There is concern that if increased exercise is accompanied by extra energy intake, preventing weight loss, the beneficial effects of exercise are lost. However, at least two studies in which weight was maintained do show a small improvement in glycaemic control and insulin sensitivity following a period of physical training (Schneider et al. 1984; Krotkiewski et al. 1985).

\section{EXERCISE AND INSULIN-DEPENDENT DIABETES MELLITUS (IDDM)}

Uncontrolled IDDM is a complex metabolic disorder. Current insulin-replacement regimens do not result in normalization of these abnormalities for prolonged periods. Under conditions of adequate insulinization, acute exercise uses up muscle glycogen and places subjects at risk of hypoglycaemia. Subjects remain at risk for some hours after exercise and this presumably reflects increased insulin sensitivity as well as continued release of subcutaneously-administered insulin. By contrast, when patients are underinsulinized, with moderate hyperglycaemia prevailing, exercise results in further elevation of blood glucose accompanied by increases in ketones, free fatty acids and counterregulatory hormones, which will have a further insulin-antagonist effect (Berger et al. 1977).

Avoiding these problems is a major focus of everyday management and Devlin (1992) has argued that attempts should be focused on devising regimens that will allow IDDM subjects to exercise safely and not promote exercise as a means of improving glycaemic control. Nevertheless, several investigators have examined influences of glycaemic control and insulin sensitivity. IDDM, especially in poor control, is an insulin-resistant state (De Fronzo et al. 1982; Lager et al. 1983; Beck-Nielsen et al. 1984; Bell et al. 1986). Lack of physical fitness may contribute to insulin resistance in adolescent IDDM patients (Arslanian et al. 1990). Exercise-induced changes in insulin action would be expected to reduce insulin-replacement requirements and contribute to some overall improvement in control. Some improvement in insulin sensitivity following regular exercise has been demonstrated (Yki Jarvinen et al. 1984; Bak et al. 1989). However, given the practical difficulties for diabetic patients already referred to, it is perhaps not surprising that a recent study failed to show lower insulin sensitivity in a group of athletes with IDDM compared with control subjects (Ebeling et al. 1995).

\section{EFFECT OF DIET AND WEIGHT LOSS ON INSULIN SENSITIVITY}

Obesity has been recognized as an insulin-resistant state for many years (Karam et al. 1963), although not all individual obese patients are significantly insulin resistant (Bogardus et al. 1985). Defining obesity in terms of a central distribution with increased waist : hip ratio makes it a more-accurate marker of insulin resistance (Evans et al. 1984) and the relationship appears most close with truncal subcutaneous fat (Abate et al. 1995). Excessive release of free fatty acids from adipocytes is a feature of obesity and may be greater in central obesity (Jensen et al. 1989). Increased free fatty acid concentrations may reduce skeletal-muscle glucose metabolism (Randle et al. 1963; Ferrannini et al. 1983) and 
provide a possible explanation for the insulin resistance of obesity. Weight loss is associated with increasing insulin sensitivity (Olefsky et al. 1974).

There is a close but complicated relationship between NIDDM and obesity. The presence of obesity, particularly of central distribution, greatly increases the subsequent risk of developing NIDDM (Ohlson et al. 1985). Many but not all patients with NIDDM are obese, although at any time most obese patients have normal glucose tolerance. Additional, possibly genetic, factors may operate to bring about decompensation by worsening insulin resistance or impairment of insulin secretion. Weight loss is also effective in reducing insulin resistance and many of the metabolic abnormalities in NIDDM, including hyperglycaemia, increased endogenous glucose production and impaired glucose uptake (Henry et al. 1986). Over 20 years ago, Hadden et al. (1975) demonstrated that much of the improvement in blood glucose and probably insulin sensitivity occurred before significant weight loss, during a period of careful dietary restriction in NIDDM.

A recent study has examined this issue in detail (Kelley et al. 1993). They devised a protocol where patients with NIDDM were studied: (a) after a baseline period when energy intake was adjusted to maintain weight; (b) after a brief period of severe energy restriction; (c) after a 12-week period when weight reduction was achieved, but concluding with gradual refeeding to stabilize weight; and (d) after a further brief period of severe energy restriction. Initial energy restriction produced substantial changes in insulin sensitivity. After significant weight loss each indicator improved further. Reimposing energy restriction after weight loss caused little further effect (Table 2).

Weight loss in obesity is associated with increased skeletal-muscle receptor tyrosine kinase activity (Caro et al. 1987) and increased content and function of GLUT 4 (Friedman et al. 1992). These mechanisms may be involved in improved insulin sensitivity due to energy restriction. In NIDDM glycogen synthase activity was not improved by weight loss (Johnson et al. 1990). Depletion of hepatic glycogen, however, is a plausible explanation for reduced endogenous glucose production after energy restriction, and muscle glycogen depletion may contribute to increased skeletal-muscle insulin sensitivity.

\section{HIGH $V$. LOW CARBOHYDRATE DIETS, INSULIN SENSITIVITY AND NON-INSULIN- DEPENDENT DIABETES}

Recommendations by both the British and American Diabetic Associations in the 1980s (Nutrition Sub-Committee of the British Diabetic Association's Medical Advisory Committee, 1980; American Diabetes Association, 1987) favoured increasing the proportion of dietary energy coming from carbohydrate associated with lowering fat intake. The American Diabetes Association (1987) specified a target of 55-60\% of energy

Table 2. Percentage of total improvement achieved during sequential periods of energy restriction and weight loss (From Kelley et al. 1993)

\begin{tabular}{lccc}
\hline \hline Regimen... & $\begin{array}{c}\text { Initial energy restriction } \\
(3.3 \mathrm{MJ}, 7 \mathrm{~d})\end{array}$ & $\begin{array}{c}\text { Period of weight loss and } \\
\text { weight stability (8 weeks } \\
\text { energy restriction plus 4 } \\
\text { weeks gradual refeeding) }\end{array}$ & $\begin{array}{c}\text { Further energy restriction } \\
(3.3 \mathrm{MJ}, 7 \mathrm{~d})\end{array}$ \\
\hline Fasting plasma glucose & 46 & 40 & 14 \\
Hepatic glucose production & 50 & 38 & 12 \\
Glucose uptake & 45 & 55 & 0 \\
\hline
\end{tabular}


from carbohydrate. This contrasted with early dietary prescriptions of severe carbohydrate restriction with most energy coming from fat intake. As well as concern that high-fat diets would increase circulating lipid concentrations, evidence also emerged that highcarbohydrate diets resulted in improved glycaemic control and/or insulin sensitivity. Some of these studies are summarized in Table 3, but the information is of limited value in providing practical advice for patients. It has been argued that the improvements in the Himsworth (1935) study occurred over a range of carbohydrate ingestion unlikely to be relevant to current practice $(10-30 \%)$. Other studies involved very high carbohydrate in liquid formulation (Brunzell et al. 1971; Kolterman et al. 1979) or in traditional AmericanIndian form (Swinburn et al. 1991).

Some of the studies failing to show a benefit of increased carbohydrate are summarized in Table 4. Relatively achievable differences in carbohydrate intake were examined and insulin action was assessed directly by glucose clamping. It seems that, within the limits of practical acceptability, increases in carbohydrate intake are themselves unlikely to be advantageous in terms of insulin sensitivity. The recent recommendations by the British and American Diabetes Associations (Nutrition Subcommittee of the Professional Advisory Committee of the British Diabetic Association, 1992; American Diabetes Association, 1994) are that more than $50 \%$ of dietary energy should be from carbohydrate sources, or rather less where the diet is high in monosaturated fat. An additional factor to be considered is the nature of carbohydrate and, in particular, fibre composition. Two shortterm studies comparing low- and high-fibre diets failed to show a convincing alteration in

Table 3. Studies suggesting improved insulin sensitivity with diets high in carbohydrate (CHO)

\begin{tabular}{|c|c|c|c|c|}
\hline Study & Subjects & Dietary CHO $(\mathrm{g} / \mathrm{kg})$ & Design & $\begin{array}{l}\text { Assessment of } \\
\text { insulin action }\end{array}$ \\
\hline Himsworth (1935) & Non-diabetic & 100 v. 300 & 1 week, compared with basal & ITT, GTT \\
\hline Brunzell et al.(1971) & Non-diabetic or IGT & 450 v. 850 & 1-2 weeks, compared with basal & GTT \\
\hline Anderson (1977) & IGT or NIDDM & 440 v. 750 & 1 week, compared with basal & IVGTT, GTT \\
\hline Kolterman et al.(1979) & Non-diabetic & 420 v. 750 & 1-2 weeks, compared with basal & GII \\
\hline Fukagawa et al.(1990) & Non-diabetic & 430 v. 680 & 3-4 weeks, compared with basal & GC \\
\hline Swinburn et al. (1991) & Non-diabetic & 300 v. 700 & 2 weeks crossover & IVGTT \\
\hline
\end{tabular}

ITT, insulin-tolerance test; GTT, oral glucose-tolerance test; IVGTT, intravenous glucose-tolerance test; GII, glucoseinsulin infusion; GC, glucose clamp; IGT, impaired glucose tolerance; NIDDM, non-insulin-dependent diabetes mellitus.

Table 4. Studies suggesting no improvement in insulin sensitivity with diets high in carbohydrate $(\mathrm{CHO})$

\begin{tabular}{llclc}
\hline \hline Study & Subjects & Dietary CHO $(\mathrm{g} / \mathrm{kg})$ & Design & $\begin{array}{c}\text { Assessment of } \\
\text { insulin action }\end{array}$ \\
\hline Borkman et al. $(1991)$ & Non-diabetic & $<400 v .>500$ & 3 weeks crossover & GC \\
Garg et al. $(1992)$ & NIDDM & $350 v .600$ & 3 weeks crossover & GC \\
Parillo et al. $(1992)$ & NIDDM & $400 v .600$ & 15 d crossover & GC \\
Hughes et al. $(1995)$ & IGT & $500 v .600$ & 12 weeks, compared & GC \\
& & & with basal & \\
\hline
\end{tabular}

GC, glucose clamp; IGT, impaired glucose tolerance; NIDDM, non-insulin-dependent diabetes mellitus. 
insulin sensitivity (Hoffman et al. 1982; Nestel et al. 1984). Effects of fibre on glycaemic control are likely to be caused in large part by delayed gastrointestinal carbohydrate absorption (Nuttall, 1993).

\section{REFERENCES}

Abate, N., Garg, A., Peshock, R. M., Stray-Gundersen, J. \& Grundy, S. M. (1995). Relationships of generalised and regional adiposity to insulin sensitivity in men. Journal of Clinical Investigation 96, 88-98.

American Diabetes Association (1987). Nutritional recommendations and principles for individuals with diabetes mellitus: 1986. Diabetes Care 10, 126-132.

American Diabetes Association (1994). Nutrition recommendations and principles for people with diabetes mellitus. Diabetes Care 17, 519-522.

Andersen, P. H., Lund, S., Schmitz, O., Junker, S., Kahn, B. B. \& Pedersen, O. (1993). Increased insulinstimulated glucose uptake in athletes: the importance of GLUT4, mRNA, GLUT4 protein and fibre type composition of skeletal muscle. Acta Physiologica Scandinavica 149, 393-404.

Anderson, J. W. (1977). Effect of carbohydrate restriction and high carbohydrate diets on men with chemical diabetes. American Journal of Clinical Nutrition 30, 402-408.

Arslanian, S., Nixon, P. A., Becker, D. \& Drash, A. L. (1990). Impact of physical fitness and glycaemic control on in vivo insulin action in adolescents with IDDM. Diabetes Care 13, 9-15.

Bak, J. F., Jacobsen, U. K., Jorgensen, F. S. \& Pedersen, O. (1989). Insulin receptor function and glycogen synthase activity in skeletal muscle biopsies from patients with insulin dependent diabetes mellitus: effects of physical training. Journal of Clinical Endocrinology 69, 158-164.

Baron, A. D., Laakso, M., Brechtel, G. \& Edelman, S. V. (1991a). Reduced capacity and affinity of skeletal muscle for insulin-mediated glucose uptake in noninsulin-dependent diabetic subjects. Effects of insulin therapy. Journal of Clinical Investigation 87, 1186-1194.

Baron, A. D., Laakso, M., Brechtel, G. \& Edelman, S. (1991b). Mechanisms of insulin resistance in insulin dependent diabetes mellitus: a major role for reduced skeletal muscle blood flow. Joumal of Clinical Endocrinology and Metabolism 73, 637-643.

Beck-Nielsen, H., Richelsen, B., Hasling, C., Nielsen, O. H., Heding, L. \& Sorensen, N. S. (1984). Improved in vivo insulin effect during continuous subcutaneous insulin infusion in patients with IDDM. Diabetes 33, 832837.

Bell, P. M., Firth, R. G. \& Rizza, R. A. (1986). Assessment of insulin action in insulin dependent diabetes mellitus using $\left[6^{14} \mathrm{C}\right]$ glucose, $\left[3^{3} \mathrm{H}\right]$ glucose and $\left[2^{3} \mathrm{H}\right]$ glucose. Differences in apparent pattern of insulin resistance depending on isotope used. Journal of Clinical Investigation 78, 1479-1486.

Berger, M., Berchtold, P., Cuppers, H. J., Drost, H., Kley, H. K., Muller, W. A., Wiegelmann, W., ZimmermannTelschow, K., Gries, F. A., Kruskemper, H. L. \& Zimmermann, H. (1977). Metabolic and hormonal effects of muscular exercise on juvenile type diabetics. Diabetologia 13, 355-365.

Bjorntorp, P., De Jounge, K., Sjostrom, L. \& Sullivan, L. (1970). The effect of physical training on insulin production in obesity. Metabolism 19, 631-638.

Bjorntorp, P., Fahlen, M., Grimby, G., Gustafson, A., Holm, J., Renstrom, P. \& Schersten, T. (1972). Carbohydrate and lipid metabolism in middle aged physically well trained men. Metabolism 21, 1037-1044.

Blair, S. N., Jacobs, D. R. \& Powell, K. E. (1985). Relationships between exercise or physical activity and other health behaviours. Public Health Reports 100, 172-180.

Bogardus, C., Lillioja, S., Mott, D. M., Hollenbeck, C. \& Reaven, G. (1985). Relationship between degree of obesity and in vivo insulin action in man. American Journal of Physiology 248, E286-E291.

Bogardus, C., Lillioja, S., Nyomba, B. L., Zurlo, F., Swinburn, B., Esposito-Del Puente, A., Knowler, W. C., Ravussin, E., Mott, D. M. \& Bennett, P. H. (1989). Distribution of in vivo insulin action in Pima Indians as mixture of three normal distributions. Diabetes 38, 1423-1432.

Bogardus, C., Ravussin, E., Robbins, D. C., Wolfe, R. R., Horton, E. S. \& Sims, E. A. H. (1984). Effects of physical training and diet therapy on carbohydrate metabolism in patients with glucose intolerance and noninsulin-dependent diabetes mellitus. Diabetes 3, 311-318.

Borkman, M., Campbell, L. V., Chisholm, D. J. \& Storlien, L. H. (1991). Comparison of the effects on insulin sensitivity of high carbohydrate and high fat diets in normal subjects. Journal of Clinical Endocrinology and Metabolism 72, 432-437.

Braun, B., Zimmermann, M. B. \& Kretschmer, N. (1995). Effects of exercise intensity on insulin sensitivity in women with non-insulin dependent diabetes mellitus. Journal of Applied Physiology 78, 300-306.

Brunzell, J. D., Lerner, R. L., Hazzard, W. R., Porte, D. \& Bierman, E. L. (1971). Improved glucose tolerance with high carbohydrate feeding in mild diabetes. New England Journal of Medicine 284, 521-524.

Caro, J. F., Sinha, M. K., Raju, S. M., Ittoop, O., Pories, W. J., Fluckinger, E. G., Meelheim, D. \& Dohm, G. L. (1987). Insulin receptor kinase in human skeletal muscle from obese subjects with and without noninsulin dependent diabetes mellitus. Journal of Clinical Investigation 79, 1330-1337. 
De Fronzo, R. A., Bonnadonna, R. C. \& Ferrannini, E. (1992). Pathogenesis of NIDDM: a balanced overview. Diabetes Care 15, 318-368.

De Fronzo, R. A., Hendler, R. \& Simonson, D. (1982). Insulin resistance is a prominent feature of insulin dependent diabetes. Diabetes 31, 795-801.

De Fronzo, R. A., Jequier, J. E., Maeder, E., Wahren, J. \& Felber, J. P. (1981). The effect of insulin on the disposal of intravenous glucose. Results from indirect calorimetry and hepatic and femoral venous catheterisation. Diabetes 30, 1000-1007.

Dela, F., Larsen, J. J., Mikines, K. J., Ploug, T., Petersen, L. N. \& Galbo, H. (1995). Insulin-stimulated muscle glucose clearance in patients with NIDDM. Diabetes 44, 1010-1020.

Dela, F., Mikines, K. J., Von Linstow, M., Secher, N. H. \& Galbo, H. (1992). Effect of training on insulin mediated glucose uptake in human muscle. American Journal of Physiology 263, E1134-E1143.

Dela, F., Ploug, T., Handberg, A., Petersen, L.N., Larsen, J. L., Mikines, K. J. \& Galbo, G. (1994). Physical training increases muscle GLUT4 protein and mRNA in patients with NIDDM. Diabetes 43, 862-865.

Devlin, J. T. (1992). Effects of exercise on insulin sensitivity in humans. Diabetes Care 15, Suppl. 4, 1690 1693.

Devlin, J. T., Hirshman, M., Horton, E. D. \& Horton, E. S. (1987). Enhanced peripheral and splanchnic insulin sensitivity in NIDDM after a single bout of exercise. Diabetes 36, 434-439.

Dowse, G. K., Zimmet, P. Z., Gareeboo, H., Alberti, K. G. M. M., Tuomilehto, J., Finch, C. F., Chitson, P. \& Tulsidas, H. (1991). Abdominal obesity and physical inactivity as risk factors for NIDDM and impaired glucose tolerance in Indian, Creole and Chinese Mauritians. Diabetes Care 14, 271-282.

Ducimetiere, P., Eschwege, E., Papoz, L., Richard, J. L., Claude, J. R. \& Rosselin, G. (1980). Relationship of plasma insulin levels to the incidence of myocardial infarction and coronary heart disease mortality in a middle aged population. Diabetologia 19, 205-210.

Ebeling, P., Bourey, R., Koranyi, L., Tuominen, J. A., Groop, L. C., Henriksson, J., Mueckler, M., Sovijarvi, A. \& Koivisto, V. A. (1993). Mechanism of enhanced insulin sensitivity in athletes. Increased blood flow, glucose transport protein (GLUT4) concentration and glycogen synthase activity. Journal of Clinical Investigation 92, 1623-1631.

Ebeling, P., Tuominen, J. A., Bourey, R., Koranyi, L. \& Koivisto, V. A. (1995). Athletes with IDDM exhibit impaired metabolic control and increased lipid utilisation with no increase in insulin sensitivity. Diabetes 44 471-477.

Eriksson, J., Franssilla-Kallunki, A., Ekstrand, A., Saloranta, C., Widen, E., Schalin, C. \& Groop, L. (1989). Early metabolic defects in persons at increased risk for noninsulin dependent diabetes mellitus. New England Journal of Medicine 321, 337-343.

Eriksson, K. F. \& Lindgarde, F. (1996). Poor physical fitness and impaired early insulin response but late hyperinsulinaemia as predictors of NIDDM in middle-aged Swedish men. Diabetologia 39, 573-579.

Evans, D. J., Murray, R. \& Kissebah, A. H. (1984). Relationship between skeletal muscle insulin resistance, insulin mediated glucose disposal and insulin binding. Effects of obesity and body fat topography. Journal of Clinical Investigation 74, 1515-1525.

Ferrannini, E., Barrett, E. J., Bevilacqua, S. \& De Fronzo, R. A. (1983). Effects of fatty acids on glucose production and utilisation in man. Joumal of Clinical Investigation 72, 1737-1747.

Firth, R. G., Bell, P. M. \& Rizza, R. A. (1986). Effect of tolazamide and exogenous insulin on insulin action in patients with non-insulin-dependent diabetes mellitus. New England Journal of Medicine 314, 1280-1286.

Friedman, J. E., Dohm, G. L., Leggett-Frazier, N., Elton, C. W., Tapscott, E. B., Pories, W. P. \& Caro, J. F. (1992). Restoration of insulin responsiveness in skeletal muscle or morbidly obese patients after weight loss. Journal of Clinical Investigation 89, 701-705.

Fukagawa, N. K., Anderson, J. W., Hageman, G., Young, V. R. \& Minaku, K. L. (1990). High-carbohydrate, high-fibre diets increase peripheral insulin sensitivity in healthy young and old adults. American Journal of Clinical Nutrition 52, 524-528.

Garg, A., Grundy, S. M. \& Unger, R. H. (1992). Comparison of effects of high and low carbohydrate diets on plasma lipoproteins and insulin sensitivity in patients with mild NIDDM. Diabetes 41, 1278-1285.

Groop, L. C., Kankuri, M., Schalin-Jantti, C., Ekstrand, A., Nikula-Ijas, P., Widen, E., Kuismanen, E., Eriksson, J., Franssila-Kallunki, A., Saloranta, C. \& Koskimies, S. (1993). Association between polymorphism of the glycogen synthase gene and non-insulin-dependent diabetes mellitus. New England Journal of Medicine 328, $10-14$.

Hadden, D. R., Montgomery, D. A. D., Skelly, R. J., Trimble, E. R., Weaver, J. A., Wilson, E. A. \& Buchanan, K. D. (1975). Maturity onset diabetes: response to intensive dietary management. British Medical Journal 3, 276-278.

Hardin, D. S., Azzarell, B., Edwards, J., Wigglesworth, J., Maianu, L., Brechtel, G., Johnson, A., Baron, A. \& Garvey, W. T. (1995). Mechanisms of enhanced insulin sensitivity in endurance trained athletes: effects of blood flow and differential expression of GLUT 4 in skeletal muscles. Joumal of Clinical Endocrinology and Metabolism 80, 2437-2446.

Harper, R., Atkinson, A. B. \& Bell, P. M. (1996). Should we use thiazide diuretics in the treatment of noninsulin dependent diabetes? Quarterly Journal of Medicine 89, 477-482. 
Helmrich, S. P., Ragland, D. R., Leung, R. W. \& Paffenbarger, R. S. (1991). Physical activity and reduced occurrence of noninsulin dependent diabetes mellitus. New England Journal of Medicine 325, 147-152.

Henry, R. R., Wiest-Kent, T. A., Scheaffer, L., Kolterman, O. G. \& Olefsky, J. M. (1986). Metabolic consequences of very low calorie diet therapy in obese non-insulin dependent diabetic and non-diabetic subjects. Diabetes 35, 155-164.

Himsworth, H. P. (1935). The dietetic factor determining the glucose tolerance and sensitivity to insulin of healthy men. Clinical Science 2, 67-94.

Hoffman, C. R., Fineberg, S. E., Howey, D. C., Clark, C. M. \& Pronsky, Z. (1982). Short-term effects of a highfiber high-carbohydrate diet in very obese diabetic individuals. Diabetes Care 5, 605-611.

Houmard, J. A., Egan, P. C., Neufer, P. D., Friedman, J. E., Wheeler, W. S., Israel, R. G. \& Dohm, G. L. (1991). Elevated skeletal muscle glucose transporter levels in exercise-trained middle-aged men. American Journal of Physiology 261, E437-E443.

Hughes, V. A., Fiatarone, M. A., Fielding, R. A., Ferrara, C. M., Elahi, D. \& Evans, W. J. (1995). Long term effects of a high carbohydrate diet and exercise on insulin action in older subjects with impaired glucose tolerance. American Journal of Clinical Nutrition 62, 426-433.

Jensen, M. D., Haymond, M. W., Rizza, R. A., Cryer, P. E. \& Miles, J. M. (1989). Influence of body fat distribution on free fatty acid metabolism in obesity. Journal of Clinical Investigation 83, 1168-1173.

Johnson, A. B., Argyraki, M., Thow, J. C., Broughton, D., Jones, I. R. \& Taylor, R. (1990). Effects of intensive dietary treatment on insulin stimulated skeletal muscle glycogen synthase activation and insulin secretion in newly presenting type 2 diabetic patients. Diabetic Medicine 7, 420-428.

Karam, J. H., Grodsky, G. M. \& Forsham, P. H. (1963). Excessive insulin response to glucose in obese subjects as measured by immunochemical assay. Diabetes 12, 197-204.

Katz, A., Nyomba, B. L. \& Bogardus, C. (1988). No accumulation of glucose in human skeletal muscle during euglycaemic hyperinsulinaemia. American Journal of Physiology 255, E942-E945.

Kelley, D. E., Wing, R., Buonocore, C., Sturis, J., Polonsky, K. \& Fitzsimmons, M. (1993). Relative effects of calorie restriction and weight loss in noninsulin dependent diabetes mellitus. Journal of Clinical Endocrinology and Metabolism 77, 1287-1293.

Kirwan, J. P., Hickner, R. C., Yarasheski, K. E., Kohrt, W. M., Wiethop, B. V. \& Holloszy, J. D. (1992). Eccentric exercise induces transient insulin resistance in healthy individuals. Journal of Applied Physiology 72, 2197-2202.

Kolterman, O. G., Greenfield, M., Reaven, G. M., Sackow, M. \& Olefsky, J. M. (1979). Effect of a high carbohydrate diet on insulin binding to adipocytes and insulin action in vivo in man. Diabetes 28, 731-736.

Krotkiewski, M., Lonroth, P., Mandroukas, K., Wroblewski, Z., Rebuffe-Scrive, M., Holm, G., Smith, U. \& Bjorntorp, P. (1985). The effects of physical training on insulin secretion and effectiveness and on glucose metabolism in obesity and type 2 (non-insulin-dependent) diabetes mellitus. Diabetologia 28, 881-890.

Laakso, M., Edelman, S. V., Brechtel, G. \& Baron, A. D. (1990). Decreased effect of insulin to stimulate skeletal muscle blood flow in obese man. A novel mechanism for insulin resistance. Journal of Clinical Investigation 85, $1844-1852$.

Lager, I., Lonnroth, P., Von Schenck, H. \& Smith, U. (1983). Reversal of insulin resistance in type I diabetes after treatment with subcutaneous insulin infusion. British Medical Journal 287, 1661-1664.

Leslie, R. D. G., Volkmann, H. P., Poncher, M., Hanning, I., Orskov, H. \& Alberti, K. G. M. M. (1986). Metabolic abnormalities in children of noninsulin dependent diabetics. British Medical Journal 293, 840-842.

Lillioja, S., Young, A. A., Culter, C. L., Ivy, J. L., Abbot, W. G., Zawadzki, J. K., Yki-Jarvinen, H., Christin, L., Secomb, T. W. \& Bogardus, C. (1987). Skeletal muscle capillary density and fiber type are possible determinants of in vivo insulin resistance in man. Journal of Clinical Investigation 80, 415-424.

Manson, J. E., Rimm, E. B., Stampfer, M. J., Colditz, G. A., Willett, W. C., Krolewski, A. S., Rosner, B., Hennekens, C. H. \& Speizer, F. E. (1991). Physical activity and incidence of non-insulin dependent diabetes mellitus in women. Lancet 338, 774-778.

Martin, B. C., Warram, J. H., Krolewski, A. S., Bergman, R. N., Soeldner, J. S. \& Kahn, C. R. (1992). Role of glucose and insulin resistance in development of type 2 diabetes mellitus: results of a 25 year follow-up study. Lancet 340, 925-929.

Mikines, K. J., Sonne, B., Farrell, P. A., Tronier, B. \& Galbo, H. (1988). Effect of physical exercise on sensitivity and responsiveness to insulin in humans. American Journal of Physiology 254, E248-E259.

Mikines, K. J., Sonne, B., Tronier, B. \& Galbo, H. (1989). Effects of acute exercise and detraining on insulin action in trained men. Journal of Applied Physiology 66, 704-711.

Nestel, P. J., Nolan, C., Bazelmans, J. \& Cook, R. (1984). Effects of a high starch diet with low or high fiber content on postabsorptive glucose utilisation and glucose production in normal subjects. Diabetes Care 7 , 207-210.

Nutrition Sub-Committee of the British Diabetic Association's Medical Advisory Committee (1980). Dietary Recommendations for Diabetics in the 1980 s - A Policy Statement by the British Diabetic Association. London: British Diabetic Association.

Nutrition Subcommittee of the Professional Advisory Committee of the British Diabetic Association (1992). Dietary recommendations for people with diabetes: an update for the 1990s. Diabetic Medicine 9, $189-202$. 
Nuttall, F. Q. (1993). Dietary fiber in the management of diabetes. Diabetes 42, 503-508.

Nuutila, P., Knuuti, M. J., Heinonen, O. J., Ruotsalainen, U., Teras, M., Bergman, J., Solin, O., Yki-Jarvinen, H., Voipio-Pulkki, L., Wegelius, U. \& Koivisto, V. A. (1994). Different alterations in the insulin-stimulated glucose uptake in athletes heart and skeletal muscle. Joumal of Clinical Investigation 93, 2267-2274.

Ohlson, L. O., Larsson, B., Svardsudd, K., Welin, L., Eriksson, H., Wilhemsen, L., Bjorntorp, P. \& Tibblin, G. (1985). The influence of body fat distribution on the incidence of diabetes mellitus: 13.5 years of follow up of the participants in the study of men born in 1913. Diabetes 34, 1055-1058.

Olefsky, J., Reaven, G. M. \& Farquhar, J. W. (1974). Effects of weight reduction on obesity. Studies of lipid and carbohydrate metabolism in normal and hyperlipoproteinemic subjects. Journal of Clinical Investigation 53, 64-76.

Parillo, M., Rivellese, A. A., Ciardullo, A. V., Capaldo, B., Giacco, A., Genovise, S. \& Riccardi, G. (1992). A high-monosaturated-fat/low-carbohydrate diet improves peripheral insensitivity in non-insulin dependent diabetic patients. Metabolism 41, 1373-1378.

Pyorala, K. (1979). Relationship of glucose tolerance and plasma insulin to the incidence of coronary heart disease: results from two population studies in Finland. Diabetes Care 2, 131-141.

Randle, P. J., Garland, P. B., Hales, C. N. \& Newsholme, E. A. (1963). The glucose-fatty acid cycle. Its role in insulin sensitivity and the metabolic disturbances of diabetes mellitus. Lancet $\mathbf{i}, 785-789$.

Reaven, G. M. (1988). Role of insulin resistance in human disease. Diabetes 37, 1595-1607.

Rosenthal, M., Haskell, W. L., Solomon, R., Widstrom, A. \& Reaven, G. M. (1983). Demonstration of a relationship between level of physical training and insulin-stimulated glucose utilisation in normal humans. Diabetes 32, 408-411.

Saad, M., Knowler, W. C., Pettitt, D. J., Nelson, R. G., Mott, D. M. \& Bennett, P. H. (1989). Sequential changes in serum insulin concentration during development of non-insulin-dependent diabetes. Lancet $\mathbf{i}, 1356-1358$.

Schneider, S. H., Amorosa, L. F., Khachadurian, A. K. \& Ruderman, N. B. (1984). Studies on the mechanisms of improved glucose control during regular exercise in type 2 (non-insulin dependent) diabetes. Diabetologia 26, 355-360.

Segal, K. R., Edano, A., Abalos, A., Albu, J., Blando, L., Tomas, M. B. \& Pi-Sunyer, F. X. (1991). Effect of exercise training on insulin sensitivity and glucose metabolism in lean, obese and diabetic men. Journal of Applied Physiology 71, 2402-2411.

Stout, R. W. (editor) (1992). Experimental atherosclerosis and diabetes mellitus. In Diabetes and Atherosclerosis, pp. 267-291. Dordrecht: Kluwer.

Swinburn, B. A., Boyce, V. L., Bergman, R. N., Howard, B. V. \& Bogardus, C. (1991). Deterioration in carbohydrate metabolism and lipoprotein changes induced by modern high fat diet in Pima Indians and Caucasians. Journal of Clinical Endocrinology and Metabolism 73, 156-165.

Taylor, A. W., Thayer, R. \& Rao, S. (1972). Human skeletal muscle glycogen synthase activities with exercise and training. Canadian Journal of Physiology and Pharmacology 50, 411-415.

Yamanouchi, K., Ozawa, N., Shinozaki, T., Suzuki, Y., Chikada, K., Maeno, H., Nishikawa, T., Kato, K., Ito, K., Oshida, Y., Shimizu, S. \& Sato, Y. (1995). Daily walking combined with diet therapy is a useful means for obese NIDDM patients not only to reduce body weight but also to improve insulin sensitivity. Diabetes Care 18, 775-778.

Yki Jarvinen, H., De Fronzo, R. A. \& Koivisto, V. A. (1984). Normalisation of insulin sensitivity in type 1 diabetic subjects by physical training during insulin pump therapy. Diabetes Care 7, 520-527.

Young, J. C., Enslin, J. \& Kuca, B. (1989). Exercise intensity and glucose tolerance in trained and nontrained subjects. Journal of Applied Physiology 67, 39-43.

Zimmet, P., Faaiuso, S., Ainuu, J., Whitehouse, S., Milne, B. \& De Boer, W. (1981). The prevalence of diabetes in the rural and urban Polynesian population of Western Samoa. Diabetes 30, 45-51. 